\title{
Dietary Willow Bark Extract for Broilers Reared Under Heat Stress
}

\author{
Mihaela SARACILA*, Tatiana Dumitra PANAITE, Petru Alexandru VLAICU, \\ Cristina TABUC, Mihai Laurentiu PALADE, Teodor GAVRIS and Rodica Diana CRISTE
}

National Research-Development Institute for Animal Biology and Nutrition (IBNA), 1, Calea Bucuresti, Balotesti, 077015, Ilfov, Romania

*corresponding author: mihaela.saracila@yahoo.com

Bulletin UASVM Animal Science and Biotechnologies 75(2)/ 2018

Print ISSN 1843-5262; Electronic ISSN 1843-536X

DOI:10.15835/buasvmcn-asb: 2018.0011

\begin{abstract}
A 28-day feeding trial was conducted on 60 , Cobb 500 broilers (14 days), assigned to 2 groups (C, E) housed in an experimental hall $\left(32^{\circ} \mathrm{C}, 23 \mathrm{~h}\right.$ light regimen). Compared to the conventional diet $\mathrm{C}$, the experimental diet (E) included 1\% white willow bark extract (WBE). At 42 days of age, 6 blood samples /group were collected and 6 broilers/ group were slaughtered and caecal content was collected. The dietary WBE didn't influence broiler performance. The serum concentrations of glycaemia, cholesterol and triglycerides were lower $(\mathrm{P}<0.05)$ in $\mathrm{E}$ group than in $\mathrm{C}$ group. $\mathrm{E}$ broilers had the lowest count $(\mathrm{P}<0.05)$ of Enterobacteriaceae, E. coli and staphylococci colony forming units in the caecal content. The inclusion of WBE $(1 \%)$ in the diet of broilers reared at $32^{\circ} \mathrm{C}$ had an hypocholesterolemiant and hypoglycaemic effect and reduced the pathogenic bacteria in the caecum.
\end{abstract}

\section{INTRODUCTION}

Heat stress is a major environmental stressor that may have deleterious effects on growth performance, nutrient availability, immunity, intestinal microbiota and welfare of broilers (Lara, and Rostagno, 2013). Gut health problems have increased since the use of antibiotic growth promoters (AGPs) as feed additives was banned in the European Union (Wegener, 2003). Celikbilek et al. (2014) showed that poultry are susceptible to the potentially pathogenic microorganism such as E. coli and Salmonella, even more in heat stress conditions. So, the use of phytogenic compounds in broiler diets can help reducing the harmful microorganisms in the intestine (Celikbilek et al. 2014). Nutritional manipulation is one of simplest and most direct methods used in poultry production to alleviate the adverse effects of heat stress (Sahin et al. 2009). Many types of plants have been tested, at different levels of inclusion, and received great interest as replacement of antibiotics in animal production (Akyildiz, and Denli, 2016).

White willow (Salix alba) has been used traditionally, as a source of bioactive compounds including salicin, polyphenols, and flavonoids (Vlachojannis et al. 2009). Among these active compounds, salicin is known best for its support of the response of the organism to the normal physiological stress (Albrecht et al. 1990). For example, Salix acutifolia contains up to $12 \%$ salicin in its bark (Koptina et al. 2010). Also, various in vitro studies have shown antioxidant activity of willow extract (Bonaterra et al. 2010; Jukic et al. 2012). The willow bark extract has been used for thousands of years but, despite its long history, few studies on animals have been published, which to support these observations (Shara et al. 2015).

The aim of the study was to assess the effect of dietary willow bark extract given to broilers (1442 days) reared at $32^{\circ} \mathrm{C}$ on performance, serum biochemical parameters and caecal bacterial population. 
Table 1. Diet formulation

\begin{tabular}{|c|c|c|c|c|}
\hline \multirow{2}{*}{ Ingredient (\%) } & \multicolumn{2}{|c|}{ Grower (14-35 days) } & \multicolumn{2}{|c|}{ Finisher (35-42 days) } \\
\hline & C & $\mathbf{E}$ & C & $\mathbf{E}$ \\
\hline Corn & 62 & 62 & 60.45 & 60.45 \\
\hline Soybean meal & 26.58 & 26.58 & 25.54 & 25.54 \\
\hline Gluten & 4 & 4 & 6 & 6 \\
\hline Oil & 2.5 & 1.5 & 3.72 & 2.72 \\
\hline White willow bark extract & - & 1 & - & 1 \\
\hline Calcium carbonate & 1.4 & 1.4 & 1.23 & 1.23 \\
\hline Monocalcium phosphate & 1.36 & 1.36 & 1.13 & 1.13 \\
\hline Salt & 0.37 & 0.37 & 0.33 & 0.33 \\
\hline Methionine & 0.26 & 0.26 & 0.25 & 0.25 \\
\hline Lysine & 0.48 & 0.48 & 0.20 & 0.20 \\
\hline Choline & 0.05 & 0.05 & 0.05 & 0.05 \\
\hline Vitamin-mineral premix* & 1 & 1 & 1 & 1 \\
\hline Total & 100 & 100 & 100 & 100 \\
\hline \multicolumn{5}{|c|}{ Calculated chemical composition } \\
\hline Metabolizable energy, kcal/kg & 3.250 & 3.250 & 3.108 & 3.108 \\
\hline Dry matter, $\%$ & 86.48 & 86.48 & 86.49 & 86.49 \\
\hline Crude protein, $\%$ & 21.5 & 21.58 & 20.4 & 20.5 \\
\hline Ether extractives, \% & 4.46 & 4.32 & 5.66 & 5.20 \\
\hline Crude fibre, \% & 3.54 & 3.54 & 3.56 & 3.56 \\
\hline Calcium, \% & 0.84 & 0.84 & 0.78 & 0.78 \\
\hline Phosphorus, \% & 0.75 & 0.75 & 0.74 & 0.74 \\
\hline
\end{tabular}

*1 $1 \mathrm{~kg}$ vitamin-mineral premix contains: $=1.350 .000 \mathrm{IU} / \mathrm{kg}$ vit. A; $300.000 \mathrm{IU} / \mathrm{kg}$ vit. D3; $2700 \mathrm{IU} / \mathrm{kg}$ vit. E; $200 \mathrm{mg} / \mathrm{kg}$ Vit. K; 200 mg/kg Vit. B1; 480 mg/kg Vit. B2; 1485 mg/kg pantothenic acid; 2700 mg/kg nicotinic acid; $300 \mathrm{mg} / \mathrm{kg}$ Vit. B6; 4 mg/kg Vit. B7; 100 mg/kg Vit. B9; 1.8 mg/kg Vit. B12; 2500 mg/kg Vit. C; 7190 mg/kg manganese; $6000 \mathrm{mg} /$ $\mathrm{kg}$ iron; $600 \mathrm{mg} / \mathrm{kg}$ copper; $6000 \mathrm{mg} / \mathrm{kg}$ zinc; $50 \mathrm{mg} / \mathrm{kg}$ cobalt; $114 \mathrm{mg} / \mathrm{kg}$ iodine; $18 \mathrm{mg} / \mathrm{kg}$ selenium; $50 \mathrm{~g}$ sodium monensin $/ \mathrm{kg}$.

Where: C- conventional diet; E- conventional diet + 1\% white willow bark extract

\section{MATERIALS AND METHODS}

The feeding trial was conducted in the experimental halls of the National ResearchDevelopment Institute for Animal Biology (IBNABalotesti, Romania), according to an experimental protocol approved by the Ethics Commission of the Institute. A total of 60, day-old Cobb 500 broiler chicks were purchased and received a conventional starter (1-14 days) diet (3000 kcal/ $\mathrm{kg}$ metabolisable energy, $22 \%$ crude protein). At the age of 14 days, the broilers were weighted and assigned to 2 groups, control group (C) and experimental group (E). The chicks were housed in an experimental hall with $32^{\circ} \mathrm{C}$ constant 
Table 2. Effect of dietary willow bark extract on broiler performance (14-42 days)

\begin{tabular}{cccccc}
\hline Item & Days & C & E & SEM & p-value \\
\hline $\begin{array}{c}\text { Body weight } \\
\text { (g/broiler) }\end{array}$ & 14 & $379.26^{\mathrm{a}}$ & $379.26^{\mathrm{a}}$ & 4.686 & 0.9993 \\
\cline { 2 - 6 } & 42 & $1923.18^{\mathrm{a}}$ & $1861.82^{\mathrm{a}}$ & 29.677 & 0.2524 \\
\hline $\begin{array}{c}\text { Average daily feed intake } \\
\text { (g/broiler/day) }\end{array}$ & $14-42$ & $92.105^{\mathrm{a}}$ & $91.59^{\mathrm{a}}$ & 1.788 & 0.6385 \\
\hline $\begin{array}{c}\text { Average daily weight gain } \\
\text { (g/broiler/day) }\end{array}$ & $14-42$ & $55.14^{\mathrm{a}}$ & $52.95^{\mathrm{a}}$ & 1.400 & 0.2696 \\
\hline $\begin{array}{c}\text { Feed conversion ratio } \\
\text { (g feed/g gain) }\end{array}$ & $14-42$ & $1.67^{\mathrm{a}}$ & $1.73^{\mathrm{a}}$ & 0.035 & 0.9644 \\
\hline
\end{tabular}

Where: ${ }^{a}$ - Not significant difference ( $\left.\mathrm{P}>0.05\right)$; SEM: standard error of the mean.

$\mathrm{C}$ - conventional diet; E- conventional diet $+1 \%$ white willow bark extract

temperature, humidity $36 \%$ and $23 \mathrm{~h}$ light regimen. The broilers had free access to the feed and water. The conventional diet formulation (group C) had corn and soybean meal as basic ingredients and with sodium monensin (50 $\mathrm{g} / \mathrm{kg}$ premix), as COXIDIN (monensin concentration, 20\%) supplied by HUVEPHARMA (Sofia, Bulgaria) in the premix (Table 1). Compared to the diet formulation for the control group (C), the formulations for the experimental group (E) included 1\% white willow bark extract (WBE) from Plant Extract, Radaia, Cluj County, Romania.

The following parameters were monitored between days 14-42: body weight (g); average daily feed intake ( $\mathrm{g}$ feed/broiler/day); average daily weight gain ( $\mathrm{g} / \mathrm{broiler} /$ day); feed conversion ratio (g feed/g gain). Mortality was recorded throughout the experimental period.

At 42 days of the feeding trial, blood samples were aseptically collected into 9-mL Vacutainer containing $14.3 \mathrm{U} / \mathrm{mL}$ of lithium heparin (Vacutest $囚$, Arzergrande, Italy) for serum biochemical assessment on an automatic BS-130 Chemistry analyser (Bio- Medical Electronics Co., LTD, China). After blood sampling, 6 broilers/ group were slaughtered by cervical dislocation and immediately bled. Carcasses were eviscerated manually and the gastrointestinal tract was excised. Caecal contents ( 2 caeca per bird) were collected aseptically in sterilized plastic tubes and preserved at $-20^{\circ} \mathrm{C}$ until the bacteriological analyses (Enterobacteriaceae, E. coli, staphylococci, lactobacilli, Salmonella spp).
A classical medium of isolation, G.E.A.M. or Levine, was used to determine the Enterobacteriaceae and the E. coli in the samples of caecal content. The samples were first immersed into a medium with lauryl sulphate (enrichment medium), properly homogenized, and left for 20-30 minutes at room temperature $\left(23-24^{\circ} \mathrm{C}\right)$. Decimal solutions up to $10^{-5}$ in medium with lauryl sulphate were prepared. Dilutions $10^{-2}-10^{-5}$ were used to seed 2 Petri dishes/dilution, on Levine medium. The Petri dishes were incubated for $48 \mathrm{~h}$ at $37^{\circ} \mathrm{C}$, and the colonies which developed in the dishes were thereafter counted. E. coli developed characteristic colonies (dark violet with metallic shining). The other Enterobacteriaceae formed either intense red, opaque colonies (lactosepositive species), or pale pink or colourless, semitransparent colonies (lactose-negative species). The results were expressed as $\log _{10}$ colony-forming units (CFU) per gram of caecal contents. The colony forming units from Enterobacteriaceae, E. coli, staphylococci and lactobacilli was determined by a colony counter (Scan 300, INTERSCIENCE France).

The effects of treatments were tested by analysis of variance using the GLM procedure of the Minitab software (version 17, Minitab ${ }^{\circledR}$ Statistical Software), with treatment as fixed effect, according to the model $Y i=T i+e i$, where $Y i$ was the dependent variable, $T i$ is the treatment and $e i$ is the error. When overall F-test was significant, differences between means were declared significant at $\mathrm{p}<0.05$ using the test of Tukey. 
Table 3. Serum biochemical parameters (average values/group)

\begin{tabular}{|c|c|c|c|c|}
\hline Item & C & $\mathbf{E}$ & SEM & p-value \\
\hline \multicolumn{5}{|c|}{ Energy profile } \\
\hline Glycaemia, mg/dL & $273.482^{\mathrm{a}}$ & $228.756^{b}$ & 8.281 & 0.0004 \\
\hline Cholesterol, mg/dL & $133.178^{\mathrm{a}}$ & $118.200^{\mathrm{b}}$ & 3.741 & 0.0350 \\
\hline Triglycerides, mg/dL & $109.208^{\mathrm{a}}$ & $85.01^{b}$ & 4.378 & 0.0002 \\
\hline \multicolumn{5}{|c|}{ Protein profile } \\
\hline Total protein $(\mathrm{g} / \mathrm{dL})$ & $2.514^{\mathrm{a}}$ & $2.502^{\mathrm{a}}$ & 0.9228 & 0.057 \\
\hline Albumin (mg/dL) & $1.596^{\mathrm{a}}$ & $3.89^{b}$ & 0.398 & $<0.0001$ \\
\hline \multicolumn{5}{|c|}{ Other biochemical parameters profile } \\
\hline Total bilirubin (mg/dL) & $0.536^{\mathrm{a}}$ & $0.670^{\mathrm{a}}$ & 0.3134 & 0.063 \\
\hline Creatinine (mg/dL) & $0.426^{\mathrm{a}}$ & $0.340^{\mathrm{a}}$ & 0.3967 & 0.039 \\
\hline Urea $(\mathrm{mg} / \mathrm{dL})$ & $3.324^{\mathrm{a}}$ & $5.966^{\mathrm{b}}$ & 0.0013 & 0.511 \\
\hline \multicolumn{5}{|c|}{ Mineral profile } \\
\hline Calcium (mg/dL) & $8.702^{\mathrm{a}}$ & $10.202^{\mathrm{b}}$ & 0.0398 & 0.382 \\
\hline Phosphorus (mg/dL) & $4.496^{\mathrm{a}}$ & $5.922^{\mathrm{b}}$ & 0.0062 & 0.300 \\
\hline Magnesium (mg/dL) & $1.232^{\mathrm{a}}$ & $1.500^{\mathrm{b}}$ & 0.0009 & 0.051 \\
\hline Iron $(\mu \mathrm{g} / \mathrm{dL})$ & $90.870^{\mathrm{a}}$ & $106.284^{\mathrm{a}}$ & 0.1903 & 5.690 \\
\hline \multicolumn{5}{|c|}{ Enzyme profile } \\
\hline ALT (TGP), U/L & $44.186^{\mathrm{a}}$ & $34.988^{\mathrm{b}}$ & 0.0223 & 2.169 \\
\hline AST (TGO), U/L & $59.832^{\mathrm{a}}$ & $49.036^{b}$ & 0.0069 & 2.287 \\
\hline Alkaline phosphatase, U/L & $63.100 \mathrm{a}$ & $47.246^{\mathrm{b}}$ & 0.0033 & 3.200 \\
\hline Gama GT, U/L & $20.906^{\mathrm{a}}$ & $19.926^{\mathrm{a}}$ & 0.6991 & 1.164 \\
\hline LDH, U/L & $948.840^{\mathrm{a}}$ & $782.272^{\mathrm{b}}$ & 0.0002 & 30.293 \\
\hline Creatine kinase, U/L & $1022.718^{\mathrm{a}}$ & $947.860^{\mathrm{a}}$ & 0.1327 & 24.498 \\
\hline
\end{tabular}

Where: C- conventional diet; E- conventional diet $+1 \%$ white willow bark extract.

ALT- Alanine aminotransferase; AST- aspartate aminotransferase; LDH- Lactate Dehydrogenase.

${ }^{\text {a-c }}$ Mean values within a row having different superscripts are significantly different by least significant difference test $(\mathrm{P}<0.05)$. SEM: standard error of the mean.

\section{RESULTS AND DISCUSSIONS}

Table 2 data show that although at the start of the feeding trial all the chicks had similar body weight (379.26g), at 42, the body weight of E group was lower than that of $\mathrm{C}$ group, but the difference was not statistically significant $(\mathrm{P}>0.05)$.
Compared to the Management guide of Cobb 500 hybrid, (reared under thermoneutral conditions), the broilers reared under heat stress had $32.68 \%$ (C) and 34.83\% (E) lower final body weight. There were no significant differences in the average daily feed intake, average daily weight gain and feed conversion ratio (14-42 days) between 
Table 4. Effect of dietary willow bark extract on the caecal microbiota of broilers (14-42 days) ( $\log _{10} \mathrm{CFU}^{*} / \mathrm{g}$ caecal content)

\begin{tabular}{ccccc}
\hline Specification & C & E & SEM & p-value \\
\hline Enterobacteriaceae, $\log _{10}$ & $10.780^{\mathrm{a}}$ & $10.094^{\mathrm{b}}$ & 0.066 & $<0.0001$ \\
\hline Escherichia coli, $\log _{10}$ & $8.982^{\mathrm{a}}$ & $8.800^{\mathrm{b}}$ & 0.018 & $<0.0001$ \\
\hline Staphylococci, $\log _{10}$ & $8.826^{\mathrm{a}}$ & $8.100^{\mathrm{b}}$ & 0.071 & $<0.0001$ \\
\hline Lactobacilli, $\log _{10}$ & $10.210^{\mathrm{a}}$ & $10.450^{\mathrm{a}}$ & 0.051 & 0.310 \\
\hline Salmonella spp. & Absent & Absent & - & - \\
\hline
\end{tabular}

Where: C- conventional diet; E- conventional diet + $1 \%$ white willow bark extract

*colony-forming units; SEM: standard error of the mean; means in the same row no common superscript significantly different $(\mathrm{P}<0.05)$.

the two groups. No mortalities were recorded in the two groups throughout the experimental period. Even though not statistically significant, feed conversion ratio was higher in group $\mathrm{E}$ than in group C. Abidin and Khatoon, (2013) revealed that the impaired growth performance of broilers subjected to high ambient temperatures may be associated with decreased feed intake, impaired digestion and metabolism. Also under heat stress condition (32 $\left.{ }^{\circ} \mathrm{C}\right)$, Criste et al. (2017) showed that the average daily weight gain and the feed conversion ratio of Cobb 500 broilers (14-35 days), were not different between the groups fed diet with rosehip or oregano powder and the C group. In contrast with this study, but under normal conditions of temperature, Harfinda et al. (2016) have shown that the use of $1000 \mathrm{mg}$ willow bark extract/l in the drinking water for the broilers improved the feed conversion ratio.

Serum biochemical parameters directly express the status of metabolism, nutrition and health of the animals (Zhu et al. 2014). The same authors showed that these indices can be used to assess the effect of willow bark extract on growth conditions, metabolism, immunity and mechanisms of broilers.

The biochemical parameters determined in the serum (Table 3) revealed several benefits of feeding the broilers with willow bark extract. Thus, all the parameters of the plasma energy profile (glycemia, cholesterol and triglycerides) were significantly $(\mathrm{P}<0.05)$ lower compared to the group C. In contrast with present work, Tang et al. (2013) show that the acute heat stress decreased insulin concentration in broilers. The reduced content of total cholesterol may reflect the hypocholesterolemic properties attributed to the dietary willow bark extract (1\%) which has a major influence on the health status of the broilers. In agreement with these results, Karimi et al. (2015) showed in a study on normolipidemic rabbits that aromatic water of Salix aegyptiaca decreased level of total cholesterol and this effect was comparable to that of simvastatin. On the other hand, Gursu et al. (2004) found increased concentrations of triglyceride, cholesterol, and HDL cholesterol in heat-stressed broilers.

Excepting the albumin and urea levels, which were significantly lower in E group than in C, the level of total protein, bilirubin and creatinine in broiler serum showed no significantly differences $(\mathrm{P}>0.05)$ between groups. Except for the iron, the calcium, phosphorus and magnesium levels in the serum of E group were significantly $(\mathrm{P}<0.05)$ higher than those in $\mathrm{C}$ group. The same trend was noticed in the enzymatic profile, where LDH concentration was significantly $(\mathrm{P}<0.05)$ lower, by $17.55 \%$, in E group than in C group (Table 3 ). Although the broilers from both groups were reared under heat stress, the ALT and AST levels in the serum of broilers fed experimental diet was significantly $(\mathrm{P}<0.05)$ lower compared to conventional diet (Table 3). In contrast with the present results, Hosseini-Vashan et al. (2015) showed that the serum activity of AST was increased significantly by the heat stress $\left(34 \pm 1^{\circ}\right.$ C, $55 \% \mathrm{RH}, 5 \mathrm{~h} /$ day) even if the broilers received diets with tomato pomace. Serum ALT and AST are 
very low under normal conditions, but when liver damages or an increase in the permeability of liver cells are present, ALT and AST are released into the blood to increase their activity (Zhang, 2011). Also, Zhang, (2011) revealed that their serum levels are sensitive indicators of liver cell damage.

The number of colony forming units of Enterobacteriaceae, E. coli and staphylococci was significantly $(\mathrm{P}<0.05)$ lower in the caecal content of $\mathrm{E}$ group compared to $\mathrm{C}$ group (Table 4). The Enterobacteriaceae populations in the caecum of E group were $6.36 \%$ lower, the E. coli were $2.03 \%$ lower, while the staphylococci were $8.22 \%$ lower. Many studies support the idea that, under heat stress, different dietary phytoadditives can reduce the pathogenic bacteria in the intestinal and caecal content of broilers (Criste et al. 2017; Vlaicu et al. 2017). A significantly decrease in the caecal populations of Escherichia coli was noticed by Khalaji et al. (2011) too, when Artemisia sieberi leaves was added to broiler diets, however, under normal conditions of temperature. Sulaiman et al. (2013) revealed that $S$. alba extract possesses antimicrobial activities, positively correlated with their antioxidant potential.

The lactobacilli populations from the caecal content of $\mathrm{E}$ group were higher than in the $\mathrm{C}$ group, but no statistically significant $(\mathrm{P}>0.05)$. Suzuki et al. (1983) noticed that the heat stress $\left(35^{\circ} \mathrm{C}\right)$ increased the counts of $E$. coli and streptococci in the small and large intestine of broilers (7-28 days), but without any change in the lactobacilli count. Salmonella spp. were absent in all samples of caecal content.

\section{CONCLUSIONS}

Broilers treated with $1 \%$ willow bark extract did not show significant differences of the growth performance. Heat $\left(32^{\circ} \mathrm{C}\right)$ decreased the body weight compared to the reference values in the Cobb 500 Management guide for broilers (42 days) reared under normal environmental temperatures. The serum levels of glycemia, cholesterol and triglycerides were lower $(\mathrm{P}<0.05)$ in $\mathrm{E}$ group than in $\mathrm{C}$ group, thus, showing the hypocholesterolemiant and hypoglycaemic effect of willow bark extract. The dietary inclusion of willow bark extract $(1 \%)$ had a positive effect $(\mathrm{P}<0.05)$ compared to group $\mathrm{C}$ in reducing, under heat stress conditions, the proliferation of pathogenic bacteria (Enterobacteriaceae, E.coli, staphylococci) in the broiler caecum.

Acknowledgments. This work was supported by one founding source (PN 1820.0102 -Romanian Ministry of Education and Research)

\section{REFERENCES}

1. Abidin, Z., Khatoon, A. (2013). Heat stress in poultry and the beneficial effects of ascorbic acid (vitamin C) supplementation during periods of heat stress. World's Poultry Science Journal, 69(1), 135-152.

2. Akyildiz, S., Denli, M. (2016). Application of plant extracts as feed additives in poultry nutrition. Scientific Papers, Series D. Animal Science, 59, 71- 74.

3. Albrecht, M., Nahrsted, A., Luepke, N. P., Theisen, N. L., Garon, G. (1990). Anti-inflammatory activity of flavonol glycosides and salicin derivatives from the leaves of Populus tremuloides. Planta Medica. 56 (6).

4. Bonaterra, G. A., Heinrich, E., Kelber, O., Weiser, D., Metz, J., Kinscherf, R. (2010). Anti-inflammatory effects of the willow bark extract STW 33-I (Proaktiv ${ }^{\circledR}$ ) in LPS-activated human monocytes and differentiated macrophages. Phytomedicine, 17:1106-1113.

5. Celikbilek, A., Deniz, G., Orman, A., Gençoglu, H., Kara, C.. (2014). Effects of a combination of dietary organic acid blend and oregano essential oil (Lunacompacid ${ }^{\circledR}$ Herbex Dry) on the performance and Clostridium perfringens proliferation in the ileum of broiler chickens. J Biol Environ Sci. 8:61- 69.

6. Criste, R. D., Panaite, T. D., Tabuc, C., Saracila, M., Soica, C., Olteanu, M. (2017). Effect of oregano and rosehip supplements on broiler (14-35 days) performance, carcass and internal organs development and gut health. AgroLife Scientific Journal, 6(1): 2285-5718.

7. Gursu, M. F., Muhittin, O., Funda, G., Kazim, S. (2004). Effects of vitamin $\mathrm{C}$ and folic acid supplementation on serum paraoxonase activity and metabolites induced by heat stress in vivo. Nutrition Research 24 157-164.

8. Harfinda, H., Rinidar, A. T., Sugito, S. M., Winaruddin dan (2016). Effect of Willow (Salix tetrasperma Roxb) Bark Extract and Cassava (Manihot esculenta Crantz) Leaf Powder Supplementation on Weight Gain of Broiler Chickens. Jurnal Medika Veterinaria, 10(1).

9. Hosseini-Vashan, S. J., Golian, A., Yaghobfar, A. (2015). Growth, immune, antioxidant, and bone responses of heat stress-exposed broilers fed diets supplemented with tomato pomace. Int J Biometeorol.

10. Jukic, M., Burcul, F., Carev, I., Politeo, O., Milos, M. (2012). Screening for acetylcholinesterase inhibition and antioxidant activity of selected plants from Croatia. Nat Prod Res, 26:1703-1707.

11. Karimi, I., Modaresi, M., Cheshmekaboodi, F., Miraghaee, S. S. (2015). The Effects of Aromatic Water of Salix aegyptiaca L. and its Major Component, 1, 4-Dimethoxybenzene, on Lipid and Lipoprotein Profiles and Ethology of Normolipidemic Rabbits. Int J Clin Toxicol, 2:55-63. 
12. Khalaji, S., Zaghari, M., Hatami, K., Hedari-Dastjerdi, S. Lotfi, L., Nazarian, H. (2011). Black cumin seeds, Artemisia leaves (Artemisia sieberi), and Camellia L. plant extract as phytogenic products in broiler diets and their effects on performance, blood constituents, immunity, and cecal microbial population. Poult. Sci. 90:2500-2510.

13. Koptina, A. V., Shyrgin, A. I., Kanarskiy, A.V., Kanarskaya, Z. A., Tarasova, E. Y., Tremasov, M. Y. (2009). Efficacy of willow bark Salix acutifolia to absorb T-2 mycotoxin. IVUZ Forest Journal 6:146-151.

14. Lara, J. Lucas, Rostagno, H. Marcos (2013). Impact of Heat Stress on Poultry Production. Animals, 3, 356-369.

15. Sahin, K., Sahin, N., Kucuk, O., Hayirli, A., Prasad, A. (2009). Role of dietary zinc in heat-stressed poultry: A review. Poultry Science, 88(10), 2176-2183.

16. Shara, M., Stohs, S. (2015). Efficacy and Safety of White Willow Bark (Salix alba) Extracts. Phytoterapy research, 29(8): 1112-1116.

17. Sulaiman, G. M., Hussien N. N., Marzoog, T. R., Abood, A. H. (2013). Phenolic content, antioxidant, antimicrobial and cytotoxic activities of ethanolic extract of Salix Alba. American Journal of Biochemistry and Biotechnology, 9 (1): 41-46.

18. Suzuki, K., Harasawa, R., Yoshitake, Y., Mitsuoka, T. (1983). Effects of crowding and heat stress on intestinal flora, body weight gain, and feed efficiency of growing rats and chicks. Jpn. J. Vet. Sci. 45: 331-338.

19. Tang, S., Yu, J., Zhang, M., Bao, E. (2013). Effects of different heat stress periods on various blood and meat quality parameters in young Arbor Acer broiler chickens. Canadian Journal of Animal Science 93, 453-460.

20. Vlachojannis, J. E., Cameron, M., Chrubasik, S. (2009). A systematic review on the effectiveness of willow bark for musculoskeletal pain. Phytother Res 23:897-900.

21. Vlaicu, P. A., Saracila, M., Panaite, T. D., Tabuc, C., Bobe, E., Criste, R. D. (2017). Effect of the dietary grape seeds and rosehip oils given to broilers (14-42 days) reared at $32^{\circ} \mathrm{C}$ on broiler performance, relative weight of carcass cuts and internal organs and balance of gut microflora. Archiva Zootechnica, 20(1):77-88.

22. Wegener, H. C. (2003). Antibiotics in animal feed and their role in resistance development. Curr Opin Microbiol 6:439-445.

23. Zhang, X. (2011). Application of total bile acid, ALT and AST in serum. Jilin Med. J. 32:4840-4841.

24. Zhu, X., Liu, W., Yuan, S., Chen, H. (2014). The Effect of Different Dietary Levels of Thyme Essential Oil on Serum Biochemical Indices in Mahua Broiler Chickens, Italian Journal of Animal Science, 13:3, 3238.

25. *** (2015) - The management guide of Cobb 500 hybrid (http:// www.cobb-vantress.com). 